\title{
L-arginine-induced esophagitis, report of six cases
}

\author{
Pedro Rivero-Borrell de la Parra*, Miguel Á. González-Cruz, Alejandro Ferreiro-Marin y \\ Pablo R. Casaubón-Garcín
}

Centro Médico ABC, Ciudad de México, México

\begin{abstract}
Background: Drug-induced esophagitis is an uncommon diagnosis in the pediatric population. The following is a report of six adolescents with L-arginine-induced esophagitis. Case reports: All patients were under treatment with L-arginine for short stature. After using the prescribed medication for 1-3 months, all cases started with severe retrosternal pain, odynophagia, and dysphagia. The upper gastrointestinal endoscopies showed ulcers located in the mid esophageal mucosa. Conclusions: In the presence of acute severe odynophagia, dysphagia, and retrosternal pain, drug-induced esophagitis should be considered as a possible diagnosis. Treatment includes liquid diet, pain control, sucralfate, omeprazole, and interruption of L-arginine. In addition, the physician should explain preventive measures focused on patient and family education on the drug side effects and precise instructions on how to take medications, as well as a careful balance of risk and benefits of any medication. At present, there are no clinical trials that support the use of L-arginine in treatment of short stature.
\end{abstract}

Key words: Esophagitis. Arginine. Endoscopy.

\section{Reporte de seis casos de esofagitis inducida por L-arginina}

\section{Resumen}

Introducción: La esofagitis inducida por medicamentos es un diagnóstico poco frecuente en pacientes pediátricos. A continuación, se describe una serie de seis casos de pacientes menores de 15 años con esofagitis inducida por L-arginina. Casos clínicos: Los seis casos se encontraban en tratamiento con L-arginina por talla baja e iniciaron con dolor retroesternal, odinofagia y disfagia de rápida instalación. Cuatro de ellos acudieron al servicio de urgencias por la intensidad de los síntomas. Los hallazgos en la endoscopia del tubo digestivo alto fueron úlceras en la mucosa del esófago a la altura del tercio medio, zona de estrechez natural por la compresión del bronquio izquierdo. Conclusiones: En presencia de odinofagia, disfagia, dolor retroesternal y el antecedente de la ingesta de L-arginina, la esofagitis inducida por fármacos debe considerarse como una posibilidad diagnóstica. El tratamiento está basado en el manejo del dolor, sucralfato, omeprazol, así como la suspensión del medicamento y medidas preventivas centradas en la educación del paciente y los familiares sobre los riesgos y beneficios de un medicamento y la forma correcta de administrarlo.

Palabras clave: Esofagitis. Arginina. Endoscopia.

\section{Correspondencia:}

*Pedro Rivero Borrell de la Parra

E-mail: peribopa@gmail.com
Fecha de recepción: 12-07-2019

Fecha de aceptación: 14-10-2019

DOI: 10.24875/BMHIM.19000109
Disponible en internet: 17-02-2020

Bol Med Hosp Infant Mex. 2020;77(1):38-41

www.bmhim.com 1665-1146/@ 2019 Hospital Infantil de México Federico Gómez. Publicado por Permanyer. Este es un artículo open access bajo la licencia CC BY-NC-ND (http://creativecommons.org/licenses/by-nc-nd/4.0/). 


\section{Introduction}

Drug-induced esophagitis is an uncommon esophageal disorder in children. Most cases of drug-induced esophagitis are related to the use of nonsteroidal anti-inflammatory drugs (aspirin), antibiotics (tetracycline, doxycycline, and clindamycin), ferrous sulfate, alendronate, ascorbic acid, quinidine gluconate, and potassium $^{1,2}$. Some cases of L-arginine-induced esophagitis have been reported in the literature. The presumptive diagnosis is based mostly on the clinical presentation and the history of ingestion of some known drugs that potentially cause esophageal injury. Barium esophagogram can detect superficial ulcers and subtle changes in the esophageal mucosa. However, the definitive diagnosis is established endoscopically ${ }^{2-5}$.

Several associated risk factors with this disease are known:

1. Low intake of fluids with the medication or lying down in supine position immediately $<30 \mathrm{~min}$ ) after taking the medication

2. Esophageal motility disorders or esophageal stenosis

3. Drugs solubility, chemical components, and contact time $^{2,4}$.

This report aimed to determine the endoscopic findings related to L-arginine esophagitis and the suggested treatment in a pediatric population.

\section{Case reports}

The clinical presentation, endoscopy findings, histopathology, and clinical course of six adolescent patients who experienced pill esophagitis on treatment with L-arginine as a treatment for short stature are described (Table 1). The main symptoms were odynophagia, retrosternal pain, and dysphagia, which led them to the emergency room. Endoscopies were performed due to acute severe pain. The findings were erosions and ulcers in the mid esophageal mucosa (Fig. 1-3). Patients were hospitalized and managed with liquid diet, proton-pump inhibitors, sucralfate, and suspending the use of L-arginine. No recurrence was reported.

\section{Discussion}

The injuries caused by drugs in the esophagus are manifested as esophagitis. The main symptoms reported are dysphagia, odynophagia, and retrosternal pain. Due to the esophageal anatomy, the most common site of

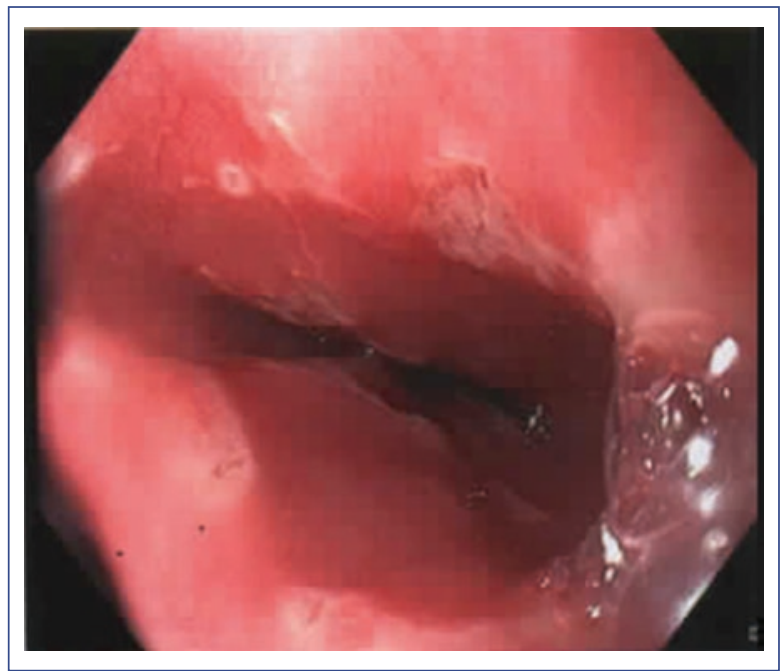

Figure 1. Isolated superficial ulcerations (mid esophagus).

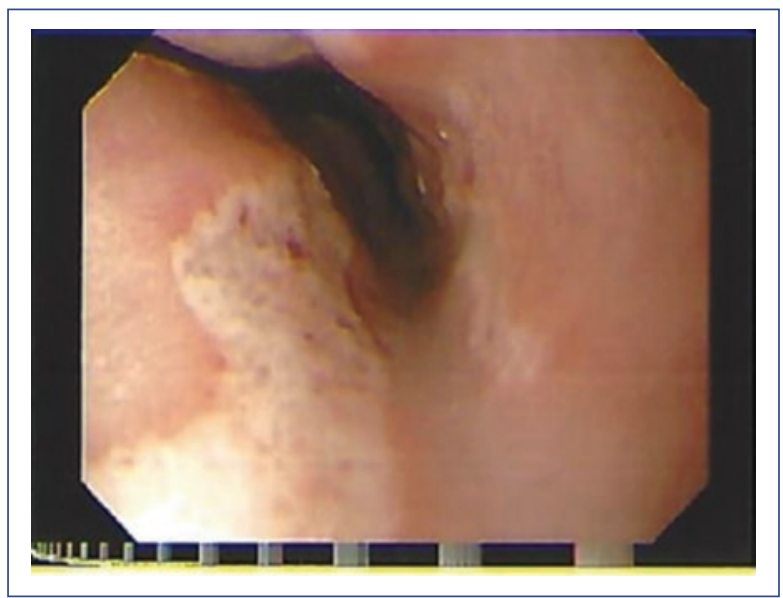

Figure 2. Linear superficial ulcerations (mid esophagus).

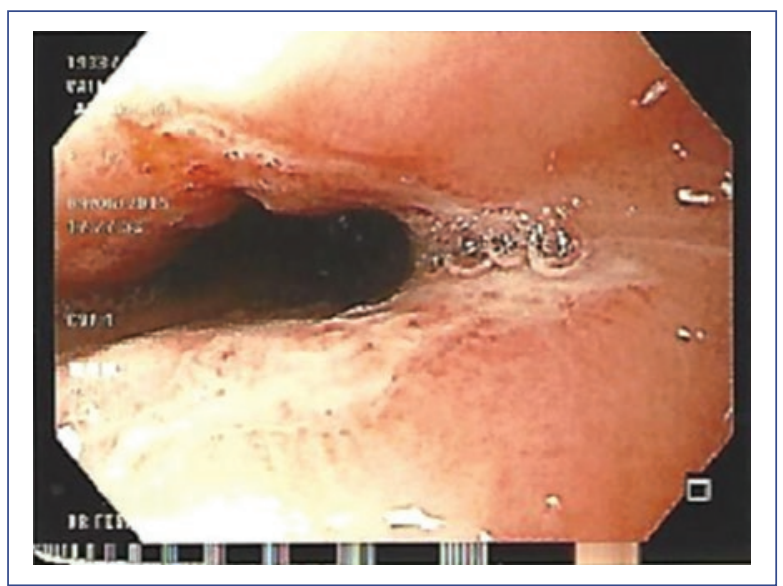

Figure 3. Circumferential ulcer in mid esophagus. 
Table 1. Age, gender, clinical presentation, doses, time of treatment with L-arginine, and histopathological findings of the cases reported

\begin{tabular}{|c|c|c|c|c|c|c|}
\hline Case & 1 & 2 & 3 & 4 & 5 & 6 \\
\hline Gender & M & M & $F$ & M & $\mathrm{F}$ & $F$ \\
\hline Age (years) & 15 & 13 & 12 & 12 & 14 & 12 \\
\hline $\begin{array}{l}\text { Doses } \\
\text { (mg/day) }\end{array}$ & 500 & 1000 & 500 & 500 & 500 & 500 \\
\hline $\begin{array}{l}\text { Time of } \\
\text { treatment with } \\
\text { L-arginine }\end{array}$ & $1 \mathrm{~m}$ & $3 \mathrm{~m}$ & $3 \mathrm{~m}$ & $1 \mathrm{~m}$ & $1 \mathrm{~m}$ & $1 w$ \\
\hline Histopathology & $\begin{array}{l}\text { Acute ulcerations } \\
\text { with regenerative } \\
\text { atypia. No fungi, } \\
\text { no viral } \\
\text { scytopathic } \\
\text { changes, no } \\
\text { metaplasia }\end{array}$ & $\begin{array}{l}\text { Acute esophagitis, } \\
\text { chronic ulcerates } \\
\text { granulation tissue, } \\
\text { epithelial } \\
\text { regeneration, no } \\
\text { metaplasia, no } \\
\text { dysplasia }\end{array}$ & $\begin{array}{c}\text { Acute } \\
\text { esophagitis, } \\
\text { chronic } \\
\text { ulcerates, with } \\
\text { multifocal thrombi } \\
\text { and fibroblast } \\
\text { proliferation }\end{array}$ & $\begin{array}{c}\text { No } \\
\text { biopsies }\end{array}$ & $\begin{array}{l}\text { Acute inflammatory } \\
\text { and plasma cell } \\
\text { infiltration. } \\
\text { Superficial } \\
\text { ulceration with } \\
\text { neutrophilic } \\
\text { reaction }\end{array}$ & $\begin{array}{l}\text { GE reflux changes } \\
\text { with acanthosis } \\
\text { spongiosis, } \\
\text { papillary } \\
\text { congestion } \\
\text { eosinophilic, PMN } \\
\text { infiltrates }\end{array}$ \\
\hline
\end{tabular}

M, male; F, female; m, month; w, week; GE, gastroesophageal; PMN, polymorphonuclear leukocytes.

injuries is the mid esophagus. However, pill esophagitis can be located at any narrowing area of the esophagus, such as the upper sphincter, the aortic arch, or compression of the left main bronchus, and the lower esophageal sphincter that could delay the passage of the pill ${ }^{4}$. Other risk factors that have been described are decreased esophageal motility, small amounts of fluid ingested with the medication, supine position, as well the size and coating of the pill5,6. Although the mechanism of injury is not precise, the direct contact of neutral or acid $\mathrm{pH}$ drugs, such as L-arginine, might produce a corrosive effect on the esophageal mucosa. None of the cases studied reported a predisposing factor such as cardiomegaly, esophageal motility disorders, stenosis, gastroesophageal reflux, achalasia, or infectious esophagitis $^{4}$. The lesions, characterized by different size ulcers, were found in the mid esophagus similar to the sites of the previous reports ${ }^{2-4,7}$.

L-arginine is used for the treatment of short stature without clear scientific bases. Although it has been shown to have a direct effect on increasing muscle volume by improving blood supply and the amount of nitric oxide in the blood, in addition to stimulating the release of growth hormone, no clinical trials support its use in this particular condition ${ }^{8-11}$.

In the presence of acute severe odynophagia, dysphagia, and retrosternal pain, and drug-induced esophagitis should be considered as a possible diagnosis. Several oral medications may cause tissue damage such as L-arginine.
Patient and family information about possible medication side effects, appropriate fluid intake with the pill, and avoiding lying down 30 min after taking the pill, should help to reduce this type of injury to the esophageal mucosa ${ }^{6,7}$.

The physician should always perform a careful balance of risk and benefits of a medication. There are no clinical trials that support the use of L-arginine for the treatment of short stature.

\section{Ethical disclosures}

Protection of human and animal subjects. The authors declare that no experiments were performed on humans or animals for this study.

Confidentiality of data. The authors declare that they have followed the protocols of their work center on the publication of patient data.

Right to privacy and informed consent. The authors have obtained the written informed consent of the patients or subjects mentioned in the article. The corresponding author is in possession of this document.

\section{Conflicts of interest}

The authors declare that they have no conflicts of interest.

\section{Funding}

None. 


\section{References}

1. Gilger MA, El-Serag HB, Gold BD, Dietrich CL, Tsou V, McDuffie A, et al. Prevalence of endoscopic findings of erosive esophagitis in children: a population-based study. J Pediatr Gastroenterol Nutr. 2008;47:141-6.

2. Bordea MA, Pirvan A, Sarban C, Margescu C, Leucuta D, Samasca G, et al. Pill-induced erosive esophagitis in children. Clujul Med. 2014; 87:15-8.

3. McGettigan MJ, Menias CO, Gao ZJ, Mellnick VM, Hara AK, Adamiak T, et al. Pill-induced esophagitis. Clujul Med. 2015;36:511-31.

4. Vãlean S, Petrescu M, Cãtinean A, Chira R, Mircea PA. Pill esophagitis. Rom J Gastroenterol. 2005;14:159-63.

5. Kikendall JW, Richter JE. Pill-induced esophagitis. Gastroenterol Hepatol (NY). 2007;3:275-6.
6. Jaspersen D. Drug-induced oesophageal disorders: pathogenesis, incidence, prevention and management. Drug Saf. 2000;22:237-49.

7. Adamiak T, Plati KF. Pediatric esophageal disorders: diagnosis and treatment of reflux and eosinophilic esophagitis. Pediatr Rev. 2018:39:392-402.

8. Cañaveral MV, Maya G, González V, Velázquez JM. Estudio del paciente con talla baja. Med Lab. 2009;15:511-31.

9. Pérez BG, Crespo JJ, Belmonte D, Bernabé CM. Úlcera esofágica por comprimido de L-arginina: causa no comunicada previamente de esofagitis por comprimidos. Farm Hosp. 2014;38:486-97.

10. Pineda RM, Aguilera ML, Bohórquez PC. Úlcera esofágica inducida por L-arginina: informe de un caso. Endoscopia. 2015;27:84-6.

11. Blanco-Rodríguez G, Reyes-Retana R, Varela-Fascinetto G, Graham-Pontones S. Esophagitis caused by L-arginine capsule retention: presentation of four cases. Rev Gastroenterol Mex. 2018;83:196-7. 